\title{
Organic Matter Controls of Iron Incorporation in Growing Sea Ice
}

\author{
Julie Janssens ${ }^{1,2,3 *}$, Klaus M. Meiners ${ }^{2,3}$, Ashley T. Townsend ${ }^{4}$ and Delphine Lannuzel ${ }^{1,2}$ \\ ${ }^{1}$ Institute for Marine and Antarctic Studies, University of Tasmania, Hobart, TAS, Australia, ${ }^{2}$ Antarctic Climate and \\ Ecosystems Cooperative Research Centre, University of Tasmania, Hobart, TAS, Australia, ${ }^{3}$ Australian Antarctic Division, \\ Department of the Environment and Energy, Kingston, TAS, Australia, ${ }^{4}$ Central Science Laboratory, University of Tasmania, \\ Hobart, TAS, Australia
}

OPEN ACCESS

Edited by:

Benjamin Allen Lange, Fisheries and Oceans Canada,

Canada

Reviewed by:

Maria A. Van Leeuwe, University of Groningen, Netherlands Andrea Niemi,

Fisheries and Oceans Canada

Canada

*Correspondence:

Julie Janssens

julie.janssens@csiro.au

Specialty section: This article was submitted to Cryospheric Sciences, a section of the journal

Frontiers in Earth Science

Received: 17 September 2017

Accepted: 26 February 2018

Published: 15 March 2018

Citation:

Janssens J, Meiners KM, Townsend AT and Lannuzel D (2018)

Organic Matter Controls of Iron Incorporation in Growing Sea Ice.

Front. Earth Sci. 6:22. doi: 10.3389/feart.2018.00022
This study presents the first laboratory-controlled sea-ice growth experiment conducted under trace metal clean conditions. The role played by organic matter in the incorporation of iron $(\mathrm{Fe})$ into sea ice was investigated by means of laboratory ice-growth experiments using a titanium cold-finger apparatus. Experiments were also conducted to understand the role of extracellular polymeric substances (EPS) in the enrichment of ammonium in sea ice. Sea ice was grown from several seawater solutions containing different quantities and qualities of particulate Fe (PFe), dissolved Fe (DFe) and organic matter. Sea ice and seawater were analyzed for particulate organic carbon and nitrogen, macro-nutrients, EPS, PFe, and DFe, and particulate aluminum. The experiments showed that biogenic PFe is preferentially incorporated into sea ice compared to lithogenic PFe. Furthermore, sea ice grown from ultra-violet (UV) and non-UV treated seawaters exhibits contrasting incorporation rates of organic matter and Fe. Whereas, the effects of UV-treatments were not always significant, we do find indications that the type or organic matter controls the enrichment of Fe in forming sea ice. Specifically, we come to the conclusion that the incorporation of DFe is favored by the presence of organic ligands in the source solution.

Keywords: sea ice, iron, EPS, organic matter, organic ligands, incorporation, Antarctica

\section{INTRODUCTION}

Sea ice is an important reservoir of iron (Fe) in the Southern Ocean (e.g., Sedwick and DiTullio, 1997; Lancelot et al., 2009; Lannuzel et al., 2010; Wang et al., 2014). Every spring, Fe contained in sea ice is released into surface waters and can trigger phytoplankton blooms in the marginal ice zone. This seasonal event represents an important source of food for higher trophic levels and potentially contributes to the biological pump in the Southern Ocean (Sullivan et al., 1993; Lannuzel et al., 2007, 2010). Climate predictions suggest sea-ice extent and volume will decrease by 24 and $34 \%$, respectively by 2100 (Arzel et al., 2006). The effect of these changes on sea-ice biogeochemical processes, and most importantly on the uptake of carbon dioxide $\left(\mathrm{CO}_{2}\right)$ in the Southern Ocean, remains enigmatic. It is therefore of primary importance to gain a mechanistic understanding of the processes leading to Fe enrichment in sea ice. This step is necessary to adequately represent ice-associated iron biogeochemistry in numerical models.

The co-occurrence of enrichment of organic matter and Fe in sea ice suggests that they are coupled (Grotti et al., 2005; Lannuzel et al., 2007, 2008, 2014a; van der Merwe et al., 2009, 2011a,b; de Jong et al., 2013, 2015; Janssens et al., 2016). It has been proposed that the Fe 
concentration in the ice depends on the Fe concentration in the parent seawater during sea-ice formation (van der Merwe et al., 2009). Dissolved organic ligands, potentially in the form of extracellular polymeric substances (EPS), are thought to control the distribution of dissolved Fe (DFe) in sea ice and might be a crucial vector of Fe enrichment in forming sea ice (Lannuzel et al., 2015; Genovese et al., in review).

EPS are produced by algae and bacteria (Meiners et al., 2004; Mancuso Nichols et al., 2005b; Meiners and Michel, 2017) and have been found to be enriched in sea ice compared to seawater (e.g., Krembs et al., 2002a, 2011; Meiners et al., 2003, 2004; Riedel et al., 2006; van der Merwe et al., 2009; Underwood et al., 2010; Ewert and Deming, 2011; Aslam et al., 2012; Janssens et al., 2016). EPS are a good candidate for metallic anion binding (Croot and Johansson, 2000; Verdugo et al., 2004) given their high stickiness and negatively charged surfaces (Decho, 1990; Underwood et al., 2010). EPS exist in a continuum of sizes from dissolved and colloidal to particulate fractions (Verdugo et al., 2004), and therefore may control the enrichment of all Fe size fractions in sea ice.

Janssens et al. (2016) showed that sea-ice formation leads to concomitant physical enrichment of EPS, particulate organic matter and $\mathrm{Fe}$, with larger particles being preferentially enriched compared to smaller particles during an in situ ice-growth experiment. Nonetheless the simultaneous investigation of physical, chemical and biological processes in field conditions is extremely difficult given the complex interactions between them. In this context, laboratory ice-growth experiments are valuable to isolate specific processes. Laboratory experiments allow the formation of sea ice in a controlled environment and from chosen source solutions.

Ice tank experiments and laboratory ice-growth experiment are numerous (e.g., INTERICE experiments in Germany-e.g., Weissenberger and Grossmann, 1998; Krembs et al., 2002b; Geilfus et al., 2012; Zhou et al., 2014; CRREL experiments in the United State of America-e.g., Kovacs, 1996; Loose et al., 2009; or SERF experiments in Canada-e.g., Galley et al., 2013; Else et al., 2015). To our knowledge, none of these studies have been conducted under the trace metal clean conditions needed to study Fe-associated processes. This study aims at understanding the basic processes leading to the incorporation of $\mathrm{Fe}$ into growing sea ice, and specifically the role of organic matter as a carrier of Fe. Experiments were performed using a titanium (Ti) coldfinger apparatus (Kuiper et al., 2003; Ewert and Deming, 2011) tailored for use under carbon and trace metal non-contaminating conditions. Experiments were conducted to understand the role of EPS in the enrichment of ammonium $\left(\mathrm{NH}_{4}^{+}\right)$in sea ice (Zhou et al., 2013) and the role of organic matter in the enrichment

\footnotetext{
Abbreviations: DFe, dissolved iron; EI, enrichment indices; EPS, extracellular polymeric substances; EPS, POC, PON and macro-nut. Exp., extracellular polymeric substances, POC, PON, and macro-nutrients experiments; Fe, iron; FEP, teflon fluorinated ethylene propylene; Ice texture Exp., ice texture experiment; Iron Exp., iron experiment; $\mathrm{NOx}$, nitrate+nitrite; $\mathrm{NH}_{4}^{+}$, ammonium; $\mathrm{PAl}$, particulate aluminum; $\mathrm{PFe}$, particulate iron; $\mathrm{PO}_{4}^{3-}$, phosphate; $\mathrm{POC}$, particulate organic carbon; PON, particulate organic nitrogen; $\mathrm{SiOH}_{4}^{-}$, silicic acid; $\mathrm{SW}$, seawater; UHP, ultra high purity; UV, ultraviolet; XG, xanthan gum; DOM, dissolved organic matter; DOC, dissolved organic carbon; $\mathrm{CO}_{2}$, carbon dioxide.
}

of $\mathrm{Fe}$ in sea ice. We first hypothesize that the quality and quantity of EPS control the rate of incorporation of particulate organic carbon (POC) and $\mathrm{NH}_{4}^{+}$into sea ice. We tested this hypothesis by undertaking a set of experiments using surface water (assumed freshly formed EPS) and deep water (assumed old/preformed EPS), where we quantified the incorporation of EPS, organic matter and inorganic macro-nutrients [hereafter referred as macro-nutrients: nitrate+nitrite: $\mathrm{NO}_{2}+\mathrm{NO}_{3}=\mathrm{NO}_{\mathrm{x}}$, silicic acid: $\mathrm{Si}(\mathrm{OH})_{4}^{-}$, phosphate: $\mathrm{PO}_{4}^{3-}$, and ammonium: $\mathrm{NH}_{4}^{+}$)] into sea ice. Our second hypothesis was that organic matter is required to incorporate $\mathrm{Fe}$ into sea ice. We tested this by undertaking a second set of experiments targeting the role that organic matter plays in the enrichment of $\mathrm{Fe}$ (DFe and particulate $\mathrm{Fe}, \mathrm{PFe}$ ) into sea ice using UV and non-UV treated seawater. The addition of desert dusts and sea-ice algae in the source solutions was also carried out to investigate the difference between lithogenic and biogenic PFe incorporation in sea ice. To our knowledge, this work constitutes the first laboratorybased ice-growth experiments conducted under trace metal clean conditions.

\section{METHODS}

\section{Experiments}

\section{Ice Texture Experiments}

The first set of experiments, Ice texture Exp., was conducted onboard RV Polarstern, and aimed at identifying the effects of different ice growth rates on ice crystal structure, i.e., ice texture. Seawater used for these experiments was collected during a winter cruise in the Weddell Sea onboard the RV Polarstern (ANT-XXIX/6, Lemke and Participants, 2014), using the ship water intake line. The ice was grown at $-10,-15$, and $-20^{\circ} \mathrm{C}$, for 24,8 , and $6.45 \mathrm{~h}$ respectively, and processed for ice texture analysis onboard the ship (Table 1).

\section{Extracellular Polymeric Substances, POC, PON, and Macro-Nutrient Experiments}

A second set of experiments, EPS, POC, PON, and macro-nut. Exp., was run during the same voyage. Seawater was collected using the ship water intake line, a CTD or a peristaltic pump (E/S Portable Sampler, Masterflex) at different locations and different water depths (Table 1) to study the incorporation of EPS, POC, and particulate organic nitrogen $(\mathrm{PON})$ and inorganic macronutrients $\left(\mathrm{NO}_{2}+\mathrm{NO}_{3}=\mathrm{NO}_{\mathrm{x}}, \mathrm{Si}(\mathrm{OH})_{4}^{-}, \mathrm{PO}_{4}^{3-}\right.$, and $\left.\mathrm{NH}_{4}^{+}\right)$into sea ice. The first source solution was surface seawater (Surface SW, ship water intake line). The second source solution was deep seawater (Deep SW) collected with the CTD at 4,300 m depth. In the third source solution (Surface SW $+\mathrm{XG}$ ), $5 \mathrm{mg}$ $\mathrm{L}^{-1}$ of xanthan gum (XG) from Xanthomonas campestris (SigmaAldrich) was added to the surface seawater sampled with a peristaltic pump (E/S Portable Sampler, Masterflex) at the icewater interface. To achieve this, a stock solution of $1,000 \mathrm{mg}$ $\mathrm{L}^{-1} \mathrm{XG}$ was made and sonicated for $60 \mathrm{~min}$ using a Bandelin Sonopuls sonicator. The stock solution was then diluted 10 times in Ultra High Purity (UHP) water (Millipore, Gradient A10) and sonicated for $30 \mathrm{~min}$ before being added to the surface seawater. 
TABLE 1 | Summary of the different cold-finger experiments.

\begin{tabular}{|c|c|c|c|c|c|}
\hline Experiment name & Treatment name & Source solution & Addition and treatment & Freezing $\mathrm{T}\left({ }^{\circ} \mathrm{C}\right)$ & Parameters \\
\hline \multirow{3}{*}{ Ice texture Exp. } & Texture $-10^{\circ} \mathrm{C}$ & \multirow{3}{*}{$\begin{array}{l}\text { RV Polarstern SW intake line, } \\
\text { Weddell Sea }\end{array}$} & - & -10 & \multirow{3}{*}{$\begin{array}{l}\text { Ice fabrics and dimensions of the } \\
\text { ice formed }\end{array}$} \\
\hline & Texture $-15^{\circ} \mathrm{C}$ & & - & -15 & \\
\hline & Texture $-20^{\circ} \mathrm{C}$ & & - & -20 & \\
\hline \multirow{3}{*}{$\begin{array}{l}\text { EPS, POC, PON and } \\
\text { macro-nut. Exp. }\end{array}$} & Surface SW & $\begin{array}{l}\text { RV Polarstern SW intake line, } \\
67^{\circ} 39 \mathrm{~S}, 5^{\circ} 31 \mathrm{~W}\end{array}$ & - & -15 & \multirow{3}{*}{$\begin{array}{l}\text { Salinity, POC, macro-nutrients } \\
\text { and EPS }\end{array}$} \\
\hline & Deep SW & $\begin{array}{c}\text { Deep SW }(4,300 \mathrm{~m}), 68^{\circ} 01 \mathrm{~S} \\
6^{\circ} 40 \mathrm{~W}\end{array}$ & - & & \\
\hline & Surface SW + XG & Surface SW, $67^{\circ} 11 \mathrm{~S}, 13^{\circ} 14 \mathrm{~W}$ & 5 mg/L Xanthan gum & & \\
\hline \multirow{5}{*}{ Iron Exp. } & $\mathrm{FSW}+\mathrm{PFe}$ & \multirow{5}{*}{$\begin{array}{l}\text { Pre-filtered (0.4 } \mu \mathrm{m}) \text { surface SW } \\
\text { from Trumpeter Bay, (Tasmania), } \\
\qquad 43^{\circ} 16 \mathrm{~S}, 147^{\circ} 39 \mathrm{E}\end{array}$} & $30 \mu \mathrm{M}$ PFe & -15 & \multirow{5}{*}{$\begin{array}{c}\text { Salinity, PFe, PAl, DFe, POC, } \\
\text { PON }\end{array}$} \\
\hline & UV-FSW + PFe & & $30 \mu \mathrm{M}$ PFe $+15 \min$ UV & & \\
\hline & $\mathrm{FSW}+\mathrm{DFe}$ & & $30 \mu \mathrm{M}$ DFe & & \\
\hline & UV-FSW + DFe & & $30 \mu \mathrm{M}$ DFe + $15 \mathrm{~min}$ UV & & \\
\hline & $\mathrm{FSW}+$ Algae & & Sea ice algae & & \\
\hline
\end{tabular}

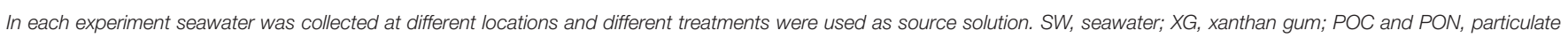
organic carbon and nitrogen; EPS, extracellular polymeric substances, FSW, filtered seawater; UV, ultra-violet; DFe, dissolved Fe; PFe, particulate Fe; PAI, particulate aluminum.

\section{Iron Experiments}

A third set of experiments, Iron Exp., aimed at assessing the role of organic matter in the incorporation of Fe into growing sea ice. Experiments were conducted under trace metal clean conditions at the University of Tasmania. Surface seawater was collected on the 9th of October 2015 from Trumpeter Bay, (Tasmania: $43^{\circ} 16 \mathrm{~S}$, $\left.147^{\circ} 39 \mathrm{E}\right)$ using a shoreline, and stored in acid-clean lowdensity polyethylene (LDPE, Nalgene) carboys. The sampling depth was approximately $2.5 \mathrm{~m}$. In the home laboratory, seawater was filtered through polycarbonate (PC) membranes (Sterlitech, pore size: $0.4 \mu \mathrm{m}$ ) at low vacuum $(<0.13 \mathrm{bar})$ using an acid-clean PC filtration apparatus (Sartorius) under a class-100 laminar flow hood (AirClean 600 PCR workstation, Model 300 Controller, AirClean System).

Filtered seawater (FSW) was divided into separate bottles for separate sets of treatments. Triplicate bottles were then spiked with different types of Fe. Added concentrations were selected to reach detectable Fe signals during analyses, despite the small volume of sea ice formed and remaining seawater. The first source solution, "FSW + PFe," was obtained by adding $30 \mu \mathrm{M}$ of lithogenic PFe $(\mathrm{PFe}>0.4 \mu \mathrm{m})$ to the FSW. Dust particles $<20 \mu \mathrm{m}$ were used, collected in the Atacama desert, Chile (European Southern Observatory, Paranal), assuming a composition of $5 \%(\mathrm{w}: \mathrm{w})$ of Fe, similar to the Earth's Crust (Taylor, 1964).

A second source solution, "FSW + DFe," was obtained by adding $30 \mu \mathrm{M}$ of DFe (DFe $<0.4 \mu \mathrm{m})$ into the FSW using a commercial solution of $1,000 \mathrm{ppm}$ of $\mathrm{FeCl}_{3}$ (Merck).

Two complementary sets of experiments were run after UVtreatment of the FSW. This UV exposure step ensured the destruction of any dissolved organic matter (DOM) present in the solution (Queroue et al., 2014). Filtered seawater was dispensed into acid-clean $0.5 \mathrm{~L}$ Teflon fluorinated ethylene propylene (FEP) bottles (Nalgene) and placed between ultraviolet lamps inside a black PVC chamber for $15 \mathrm{~min}$. After UV exposure, PFe or DFe was added to the source solution following the steps adopted in treatments "FSW + PFe" and "FSW + DFe." The latter treatments are referred to as "UV-FSW + PFe" and "UV-FSW + DFe."

A final experiment was carried out using FSW to which $44 \mathrm{~mL}$ of melted bottom sea ice containing algae was added. The ice sample was collected at Davis station, Antarctica in November 2015 and maintained under optimum growth conditions in the IMAS culture room until the start of the experiment. This treatment, named "FSW + Algae," aimed at studying the incorporation of biogenic PFe in sea ice. A list of the treatments is given in Table $\mathbf{1}$.

\section{Sea-Ice Growth Set-Up}

The experimental set-up and manipulations were conducted in a custom-made clean plastic bubble in a $4^{\circ} \mathrm{C}$ cold room onboard RV Polarstern (Ice texture Exp., EPS, POC, PON, and macronut. Exp.); and under a class-100 laminar flow hood (AirClean 600 PCR workstation, Model 300 Controller, AirClean System) in a $4^{\circ} \mathrm{C}$ cold room in the home-laboratory for experiments on the incorporation of Fe and organic matter (Iron Exp.). Ice was grown using a cold-finger apparatus first described by Kuiper et al. (2003) and Ewert and Deming (2011), modified for use under carbon and trace metal non-contaminant conditions. The cold-finger was fully made of titanium (Ti) and cooled with a circulating bath (Wise Circu, WCR-P22) using ethanol as coolant (Figure 1).

The cold-finger was immersed straight in a custom-cut square acid-clean 2 L PC container (Nalgene) filled with different source solutions of seawater (Table 1). The PC container was placed into an insulated box made of foam insulation sheet (TechLite ${ }^{\circledR}$ ) and placed on a magnetic stirrer to insure the homogeneity of the source solutions during the experiments.

At the end of each 8-h experiment, the ice was carefully removed from the remaining seawater and extracted from the 


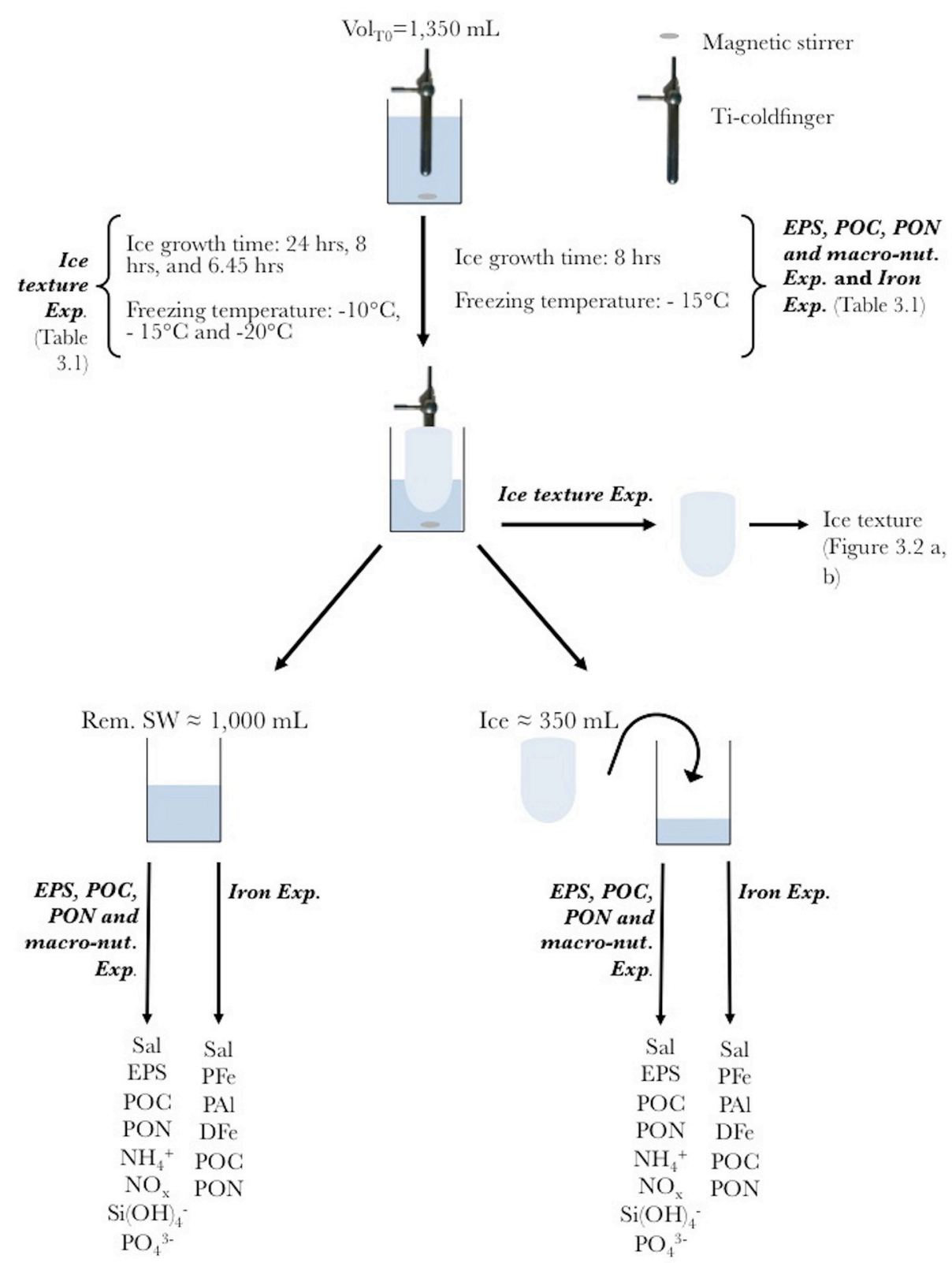

FIGURE 1 | Schematic of the cold-finger experiment for the Ice texture Experiment (Ice texture Exp.), the Extracellular polymeric substances, POC, PON, and macro-nutrients experiment (EPS, POC, PON, and macro-nut Exp.) and the iron experiment (Iron Exp.). The entire set-up was placed in a custom-made clean plastic bubble (Ice texture Exp. and EPS, POC, PON, and macro-nut. Exp.), or under a laminar flow hood (Iron Exp.). The cold-finger was connected to a circulating water bath with ethanol (not shown). Experiments were run in triplicate. For each experiment the volume at $\mathrm{T}_{0}$ was $1,350 \mathrm{~mL}$. The ice was formed at $-10,-15$, and $-20^{\circ} \mathrm{C}$ for 24,8 , and $6.45 \mathrm{~h}$ respectively for the Ice texture Exp., and $-15^{\circ} \mathrm{C}$ for $8 \mathrm{~h}$ for the EPS, POC, PON, and marco-nut. Exp. and the Iron Exp. Once formed, the ice was removed from the cold-finger, and processed for ice texture (Ice texture Exp.), or allowed to melt in the dark at room temperature before further processing (EPS, $P O C, P O N$, and macro-nut. Exp. and Iron Exp.). Both remaining seawater (Rem. SW) and ice were processed for parameters described in the method section.

cold-finger. Ice was allowed to melt at room temperature in an acid-clean PC container, following methods from Rintala et al. (2014). A diagram of the experimental set-up and workflow is shown in Figure 1. Both remaining seawater and melted ice were analyzed for the list of parameters described below. Prior to each treatment a $\mathrm{T}_{0}$ sample was collected for measurements of the same parameters in the source solution.

\section{Physical Variables: Salinity and Ice Texture}

Salinities (practical salinity, $\mathrm{S}_{\mathrm{P}}$ ) of seawater, bulk ice (melted bulk-ice sample) and remaining seawater were measured using a portable salinity probe (YSI Incorporated model 30, precision \pm 0.1 ). Vertical and horizontal thin sections of the ice were prepared following the method of Langway (1958). Thin sections were observed through 2 cross-polarized filters and 
photographed following methods described in detail in Janssens et al. (2016).

\section{Biogeochemical Variables Extracellular Polymeric Substances}

Melted ice and seawater samples were homogenized and filtered onto $25 \mathrm{~mm}$ diameter PC membranes $(0.4 \mu \mathrm{m}$, Millipore) under low vacuum $(<0.13$ bar) to avoid cell lysis. Filters were stained with $500 \mu \mathrm{L}$ of a solution of Alcian Blue (AB, GX8 Sigma, $0.02 \%$ $\mathrm{AB}$ in $0.06 \%$ acetic acid). Excess dye was removed by rinsing the membrane with $2 \mathrm{~mL}$ of UHP water (Millipore, Gradient A10). Membranes were then stored individually at $-20^{\circ} \mathrm{C}$ in the dark until analysis. Concentrations were determined colorimetrically using the method of Passow and Alldredge (1995) and modified by van der Merwe et al. (2009). Concentrations were computed using the filter capture efficiency of $4 \%$ from van der Merwe et al. (2009).

\section{Dissolved and Particulate Organic Material and Macro-Nutrients}

All glassware used for POC and PON analysis were soaked in a $2 \%(\mathrm{v}: \mathrm{v}) \mathrm{HCl}$ solution (analytical grade Merck EMSURE Germany), rinsed with UHP water, wrapped in aluminum foil and combusted at $450^{\circ} \mathrm{C}$ for $4 \mathrm{~h}$. In between triplicates and treatments, glassware was rinsed with UHP water, soaked in a $2 \%$ (v:v) $\mathrm{HCl}$ solution (analytical grade, Merck EMSURE Germany) for $8 \mathrm{~h}$ and rinsed thoroughly with UHP water. Samples for POC and PON were filtered onto pre-combusted $25 \mathrm{~mm}$ quartz filters (Sartorius). A $20 \mathrm{~mL}$ subsample of the filtrate was collected and stored at $-20^{\circ} \mathrm{C}$ in the dark until analysis for macro-nutrient concentrations $\left(\mathrm{NO}_{\mathrm{x}}, \mathrm{Si}(\mathrm{OH})_{4}^{-}, \mathrm{PO}_{4}^{3-}\right.$, and $\left.\mathrm{NH}_{4}^{+}\right)$. POC and PON samples were stored at $-20^{\circ} \mathrm{C}$ in the dark until analysis. After acidification of the filters [30 $\mu \mathrm{L}$ of $10 \%$ (v:v) $\mathrm{HCl}$, Ajax Finichem] to remove inorganic carbon, POC and PON concentrations were determined using a Thermo Finnigan EA 1112 Series Flash Elemental Analyzer (precision 1\%) at Central Science Laboratory (CSL, University of Tasmania). Silicic acid was analyzed using a photometric analyzer (Aquakem 250) and $\mathrm{PO}_{4}^{3-}, \mathrm{NO}_{\mathrm{x}}$, and $\mathrm{NH}_{4}^{+}$were analyzed with a Lachat Flow injection analyzer following the methods of Grasshoff et al. (2009). Detection limits were 0.1 and $0.002 \mathrm{mg} \mathrm{L}^{-1}$ for each method, respectively.

\section{Iron and Aluminum}

All sampling LDPE bottles, PC containers, PC filtration sets, petri-dishes and other equipment in contact with the samples were cleaned following GEOTRACES recommendations (Cutter et al., 2017). Polycarbonate membranes for PFe and PAl were soaked in $10 \%$ (v:v) ultrapure $\mathrm{HCl}$ for a week, thoroughly rinsed with UHP water (Barnstead International, NANOpure Diamond polisher) and stored in UHP water until use. Before and between treatments and triplicates, the cold-finger was thoroughly rinsed with UHP water. Between triplicates, equipment used for $\mathrm{Fe}$ filtrations was thoroughly rinsed with UHP water, soaked in a $10 \%(\mathrm{v}: \mathrm{v}) \mathrm{HCl}$ solution for $16 \mathrm{~h}$ and rinsed 5 times with UHP water.
Immediately after removing the ice from the PC bottle, the remaining seawater was filtered onto $0.4 \mu \mathrm{m}$ pore size $47 \mathrm{~mm}$ diameter PC membrane filters (Sterlitech) using an acid-clean PC filtration set (Sartorius) under gentle vacuum $(<0.13$ bar $)$. The filter was collected for measurements of PFe and PAl (particles $>0.4 \mu \mathrm{m}$ ) concentrations, and placed in acid-clean polystyrene petri-dishes. $60 \mathrm{~mL}$ of the filtrate was collected in LDPE bottles (Nalgene) and acidified to $\mathrm{pH} 1.8$ with ultrapure $\mathrm{HCl}$ (Seastar from Choice Analytics) for DFe analysis. Once fully melted, the same process was applied to the melted sea ice. Filters were stored individually in acid-clean petri-dishes, triple bagged and kept at $-20^{\circ} \mathrm{C}$ in the dark until analysis. The LDPE bottles containing the dissolved fraction were triple bagged and kept at ambient temperature until analysis.

Filters for PFe and PAl determination were digested using a mixture of strong acids following the method described in Bowie et al. (2010). Dissolved Fe samples were diluted 10 times to reduce sea salt matrix interferences effects during analysis. Particulate metals and DFe concentrations were then measured at the Central Science Laboratory (University of Tasmania) using a Sector Field Inductively Coupled Plasma Mass Spectrometer (ICP-MS, Element 2), following methods described in Bowie et al. (2010).

\section{Segregation Coefficient and Enrichment Index}

The partition coefficient, $\mathrm{K}_{\mathrm{eff}}$ is used to describe the proportion of solute that is retained in sea ice.

$$
K_{\text {eff } X}=[X]_{\text {ice }} /[X]_{\text {source }}
$$

where $[X]_{\text {ice }}$ and $[X]_{\text {source }}$ is the concentration of the component $\mathrm{X}$ in the ice and in the source solution, respectively.

To assess the enrichment of each component in the ice compared to sea salt, the enrichment index was calculated $\left(\mathrm{EI}_{\mathrm{X}}\right.$, Gradinger and Ikävalko, 1998).

$$
E I_{x}=[\text { Sal }]_{\text {source }} /[\text { Sal }]_{\text {ice. }} \cdot[X]_{\text {ice }} /[X]_{\text {source }}
$$

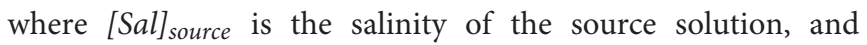
$[\text { Sal] }]_{i c e}$ is the salinity of the ice. Enrichment index of $1,<1$ or $>1$ will correspond to conservative, depletion or enrichment, respectively, of the component $\mathrm{X}$ as compared to bulk salinity.

\section{Statistical Analysis}

All statistical analyses were conducted using the statistical software R (version 3.3.3, R development Core Team, 2017). Differences in treatments were tested with standard analysis of variance (ANOVA) after log-transforming the response parameters to stabilize the variance (graphical diagnosis: Residuals vs. Fitted values, Normal quantiles vs. Standardized residuals, Scale location and Constant leverage). ANOVA was followed by a single-step multiple comparison Tukey-Honest Significant Differences (Tukey-HSD) procedure to determine which treatments differ. When the ANOVA showed no evidence of treatments differences for EIs, a $t$-test was performed to assess if the overall mean (of all treatments) of the EI was different from 1 . 


\section{RESULTS}

\section{Ice Texture and Salinity}

The ice texture was dominated by columnar ice (Figures 2A,B). The texture reflected the geometry of the cold-finger. Except for small differences in the size of the ice crystals, temperature had no effect on the geometry of the ice crystals.

Salinities of bulk-ice samples, as well as in the remaining seawater, were consistent throughout the experiments, with a mean bulk-ice salinity of $14.5 \pm 1.3 \mathrm{~S}_{\mathrm{P}}$ (mean \pm standard deviation $(S D), n=24)$, and a mean salinity of $39.6 \pm 1.3(n=24)$ for remaining seawater. The different growth temperatures applied to the samples resulted in similar partition coefficients (mean $\mathrm{K}_{\mathrm{eff}}=0.32 \pm 0.07, n=3$ ).

\section{Extracellular Polymeric Substances, POC, PON, and Macro-Nutrients Experiments} Enrichment Indices of Macro-Nutrients and EPS

Figure 3 shows the enrichment indices for EPS and macronutrients in sea ice grown from Surface SW, Deep SW and Surface SW + XG. The horizontal line marks the $\mathrm{EI}=1$ (i.e., conservative incorporation). Results show that $\mathrm{Si}(\mathrm{OH})_{4}^{-}$, $\mathrm{NO}_{\mathrm{x}}$, and $\mathrm{PO}_{4}^{3-}$ behave conservatively during sea-ice formation, whatever the source solution may be. Enrichment indices were close or equal to one for the macro-nutrients in Surface SW, Deep $S W$ and Surface $S W+X G$ (mean $\pm S D=1.0 \pm 0.09, n=9)$, except $\mathrm{NH}_{4}^{+}$that was enriched in the ice in each treatment. The largest signal was observed for $\mathrm{NH}_{4}^{+}$, which is clearly enriched in sea ice compared to seawater, especially in the deep samples (Figure 3). We observed moderate evidence of a difference in incorporation of $\mathrm{NH}_{4}^{+}$between treatments (ANOVA $F=5.28, P$ $=0.082$ ). A Tukey-HSD multiple comparison procedure showed that only the Deep SW and Surface SW + XG treatments could be distinguished $(P=0.07)$. EPS enrichment was variable and showed no significant differences (ANOVA $F=2.03, P=0.212$ ) between treatments. The highest $\mathrm{EI}_{\mathrm{EPS}}$ was observed in the Surface SW treatment and the lowest EI EPS was observed in the Deep SW treatment (Figure 3). The Deep SW experiment had the highest $\mathrm{EI}_{\mathrm{NH}_{4}^{+}}$and also the lowest $\mathrm{EI}_{\mathrm{EPS} \text {. }}$

\section{Enrichment Indices of POC and PON}

All EI $I_{P O C}$ and EI $I_{P O N}$ were well above 1 indicating an enrichment of POC and PON in newly-formed ice (Figure 4). Mean EIPOC and $\mathrm{EI}_{\mathrm{PON}}$ were $50.5 \pm 35.7(n=9)$ and $8.9 \pm 6.4(n=9)$, respectively. There is no evidence of treatment difference for EI $_{\text {POC }}$ (ANOVA $F=1.99, P=0.186$ ), and strong evidence of treatment difference for $\mathrm{EI}_{\mathrm{PON}}$ (ANOVA $F=11.23, P=$ 0.005; Tukey-HSD Surface SW + XG and Deep SW, $P=0.038$; Tukey-HSD Surface SW + XG and Surface SW, $P=0.005)$.

\section{Iron Experiments}

\section{Enrichment Indices of PFe and DFe}

Figure 5 shows the enrichment indices for DFe and PFe in sea ice grown from the five different source solutions. The horizontal line marks the $\mathrm{EI}=1$ (i.e., conservative incorporation). Results show that DFe and PFe do not behave conservatively during sea-ice formation in any of the source solutions. Dissolved Fe was slightly enriched in sea ice compared to the source seawater solution in each treatment $\left(\mathrm{EI}_{\mathrm{DFe}}>1, t\right.$-test confidence level $95 \%$, $P=0.002$ ) and relatively stable between treatments (mean $\mathrm{EI}_{\mathrm{DFe}}$ $=2.2 \pm 0.9$, Figure 5) with no evidence that $\mathrm{EI}_{\mathrm{DFe}}$ differed across treatment groups (ANOVA $F=1.85, P=0.196$ ).

We observed a strong evidence of difference in incorporation of PFe between treatments (ANOVA $F=5.17, P=0.035$ ). The UV-FSW + DFe and FSW + Algae treatments groups could be distinguished at the 0.05 level (Tukey-HSD, $P=0.02$ ). Ice was enriched in PFe in the treatments where lithogenic or biogenic PFe was added: FSW + PFe $\left(\mathrm{EI}_{\mathrm{PFe}}=1.3 \pm 1.41, n\right.$ $=3)$ and FSW + Algae $\left(\mathrm{EI}_{\mathrm{PFe}}=4.7 \pm 2.8, n=3\right.$; Figure 5). When lithogenic PFe was added and UV treatment applied, less $\mathrm{PFe}$ was incorporated in sea ice (UV-FSW $+\mathrm{PFe}, \mathrm{EI}_{\mathrm{PFe}}=0.5$ $\pm 0.3, n=3$ ) than without UV-treatment. The treatment where biogenic PFe was added (FSW + Algae) showed the highest EIPFe of all treatments $\left(\mathrm{EI}_{\mathrm{PFe}}=4.7 \pm 2.8, n=3\right)$.

\section{Enrichment Indices of POC and PON}

Particulate organic matter (POC and PON) was more enriched in sea ice in treatments where PFe was added than in treatments where DFe was added (EIPOC: ANOVA, $F=23.14, P=0.003$; and EI $_{\mathrm{PON}}$ : ANOVA, $\left.F=24.57, P=0.000\right)$. Unlike other parameters, POC was the only compound showing a higher EI in UV-treated than in its non-UV treated equivalent. The enrichment index of PON was always lower than EI POC (ANOVA, $F=4.48, P=0.040$; Figure 6).

Overall, the FSW + DFe and UV-FSW + DFe treatments had the lowest EIs and the lowest variability with EIPON of $1.1 \pm 0.7$, $n=3$ and $0.8 \pm 0.5, n=3$, respectively.

The treatments with addition of lithogenic and biogenic PFe, and no UV treatment (FSW + PFe and FSW + Algae) were the only ones where enrichment in all compounds (DFe, PFe, POC, and PON) was observed relative to the source solution (Figures 5, 6). This was not the case for the treatments where DFe was added (FSW + DFe and UV-FSW + DFe), or when UV light was applied, where, depending on the compound, enrichment or depletion was observed.

\section{Particulate Fe to Particulate Al Ratios}

Aluminum can be used as a tracer of lithogenic $\mathrm{Fe}$ inputs (Lannuzel et al., 2014a). The PFe/PAl molar ratio in the ice was elevated in all treatments compared to the Earth crustal ratio of 0.33 (Taylor, 1964). Two different patterns were observed: In the treatments with addition of PFe (FSW + PFe, UV$\mathrm{FSW}+\mathrm{PFe}$ and FSW + Algae), $\mathrm{PFe} / \mathrm{PAl}$ was higher in the ice than in the remaining seawater (Figure 7A), however, this was not statistically significant (ANOVA $F=0.68, P=0.423$ ). In these treatments, the $\mathrm{PFe} / \mathrm{PAl}$ ratios in the ice were up to 2 times higher than the crustal ratio (Figure 7A). In the treatment with DFe addition (FSW + DFe and UV-FSW + $\mathrm{DFe}$ ) the $\mathrm{PFe} / \mathrm{PAl}$ ratio in the ice was lower than in the remaining seawater (ANOVA $F=9.60, P=0.011$ ). In these experiments with addition of $\mathrm{DFe}$, the $\mathrm{PFe} / \mathrm{PAl}$ ratios were two to three orders of magnitudes higher than the crustal ratio (Figure 7B). 


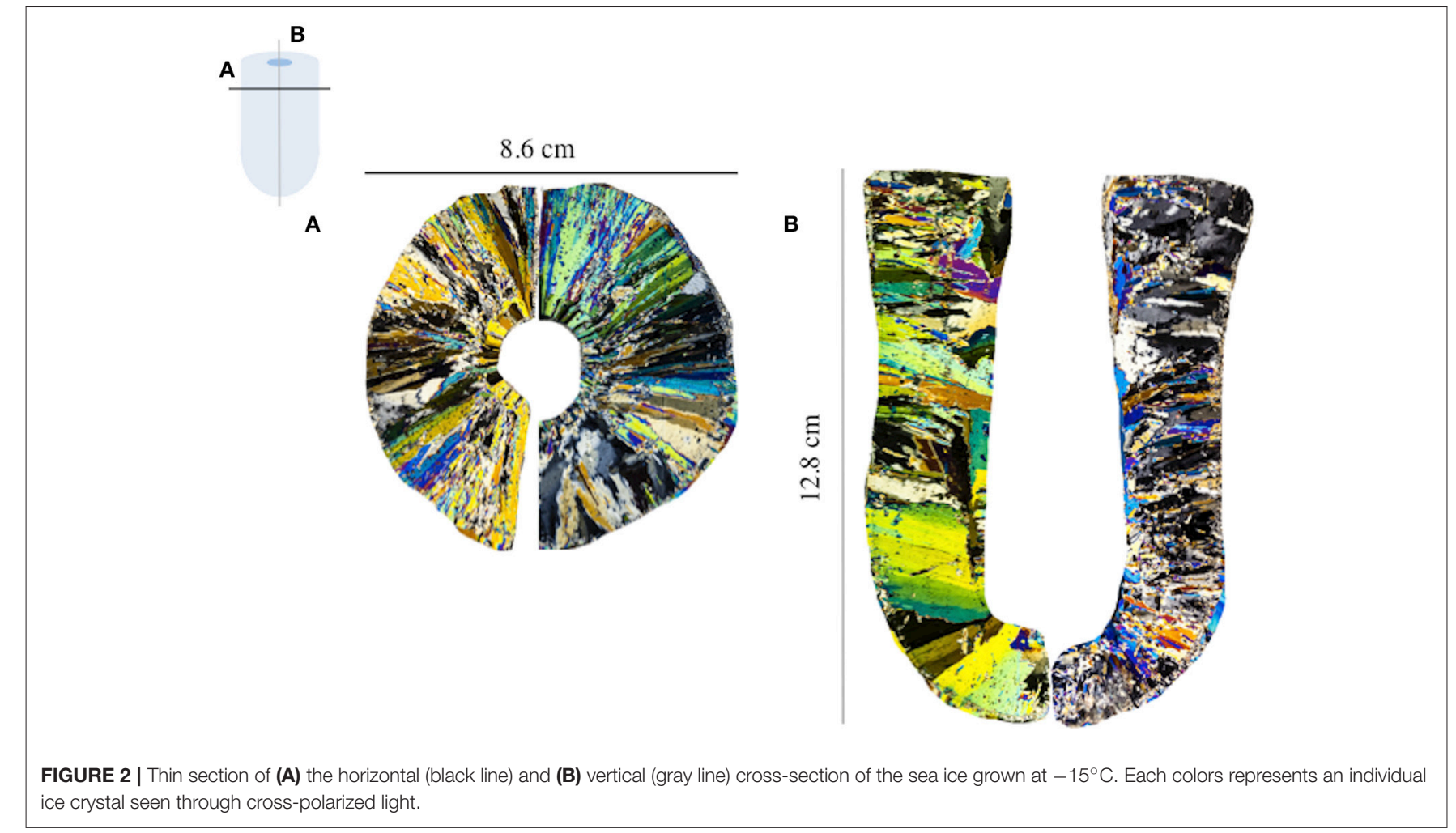

ice crystal seen through cross-polarized light.

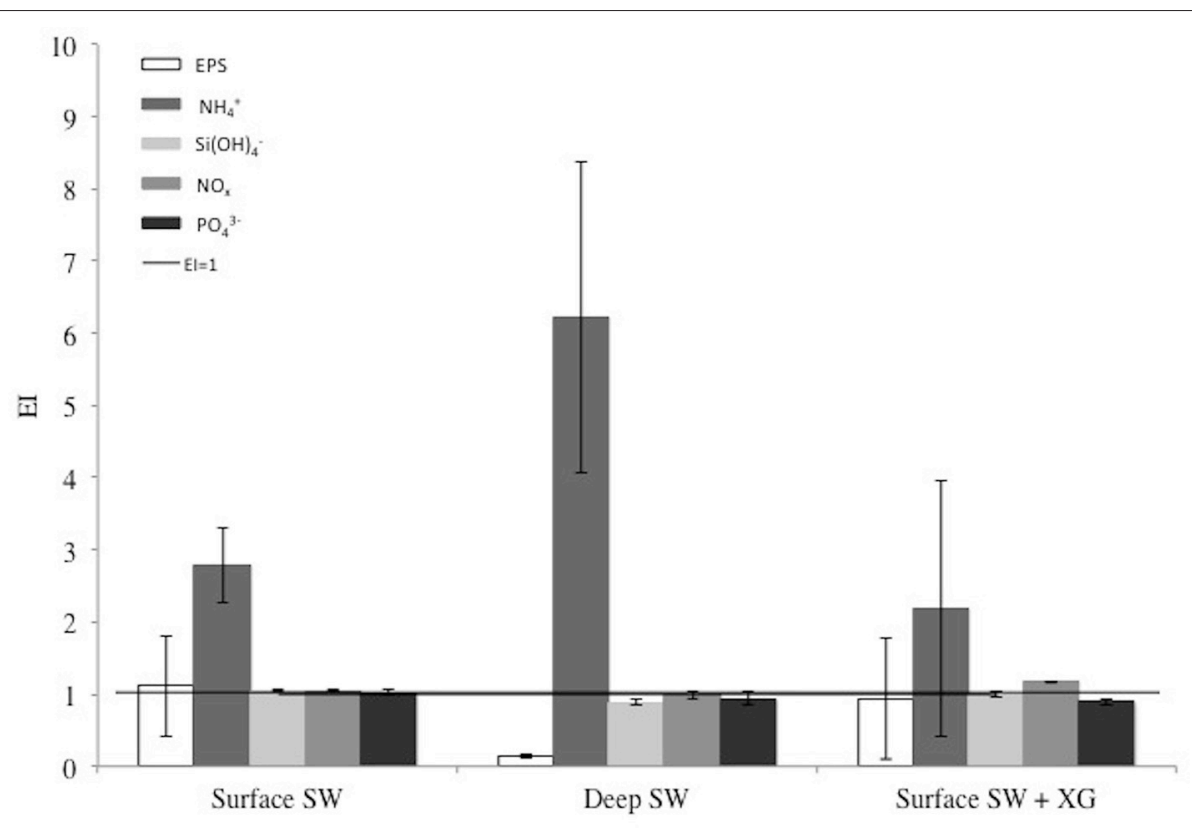

FIGURE 3 | Enrichment indices (El) of extracellular polymeric substances (EPS), ammonium $\left(\mathrm{NH}_{4}^{+}\right)$, silicic acid $\left(\mathrm{Si}(\mathrm{OH})_{4}^{-}\right)$, nitrate + nitrite $\left(\mathrm{NO}_{\mathrm{x}}\right)$, and phosphates $\left(\mathrm{PO}_{4}^{3-}\right)$ in the EPS, POC, PON, and macro-nut. Exp. The error bars represent the standard deviation between triplicates $(n=3)$. The black line shows the limit between enrichment $(E \mid>1)$ or depletion $(E \mid<1)$ of each compound.

\section{DISCUSSION}

The similarity in bulk ice and remaining seawater salinities between the different sets of experiments shows the reproducibility of our experimental set-up. Despite the unusual ice texture of the samples (horizontal ice crystals), representative processes of the natural environment are shown with the conservative behavior (i.e., relative to salt) of macro-nutrients, 


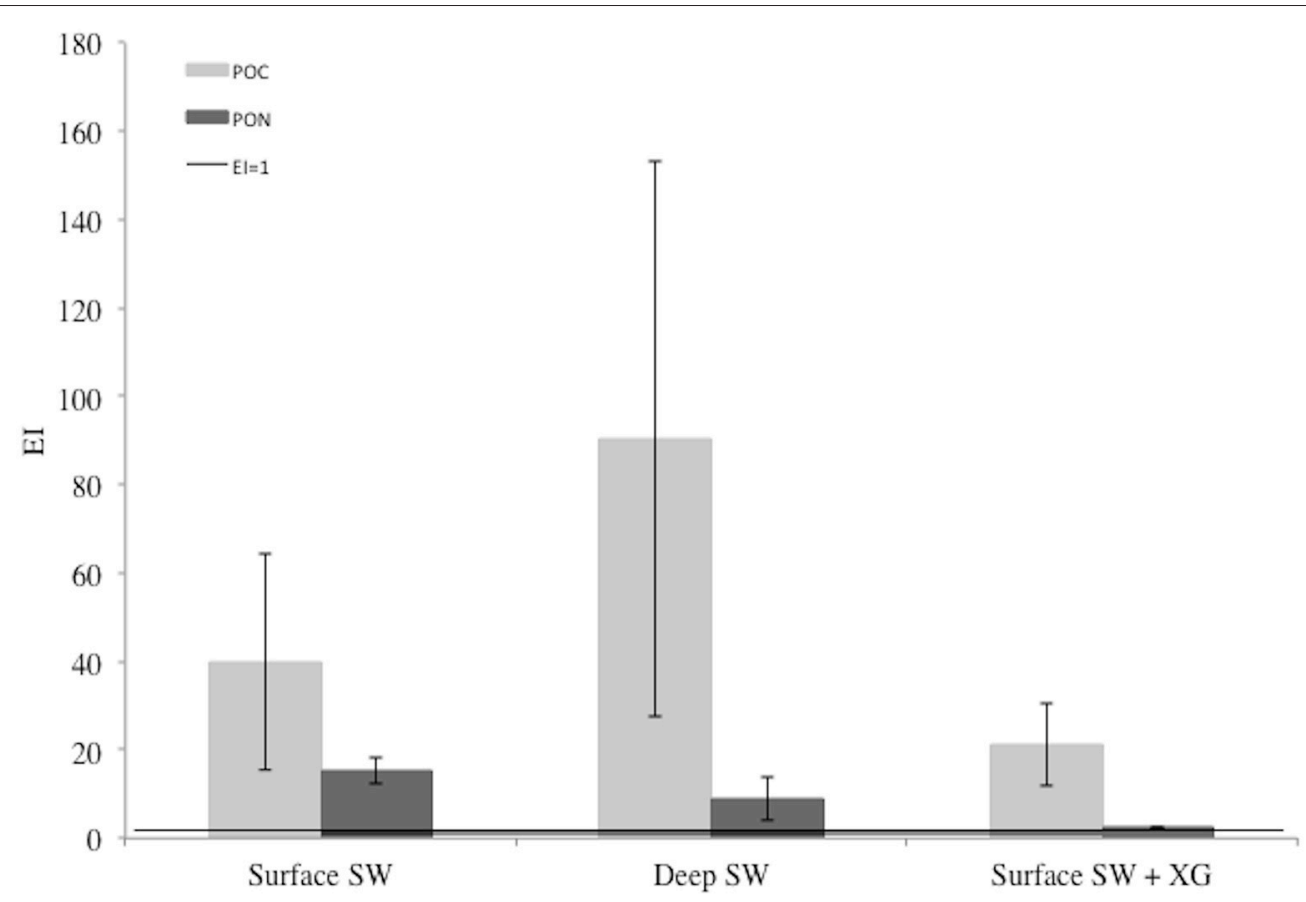

FIGURE 4 | Enrichment indices (EI) of particulate organic carbon (POC) and nitrogen (PON) in the EPS, POC, PON, and macro-nut. Exp. The error bars represent the standard deviation between triplicates $(n=3)$. The black line shows the limit between enrichment $(E l>1)$ or depletion $(E \mathrm{E}<1)$ of $\mathrm{POC}$ or PON.

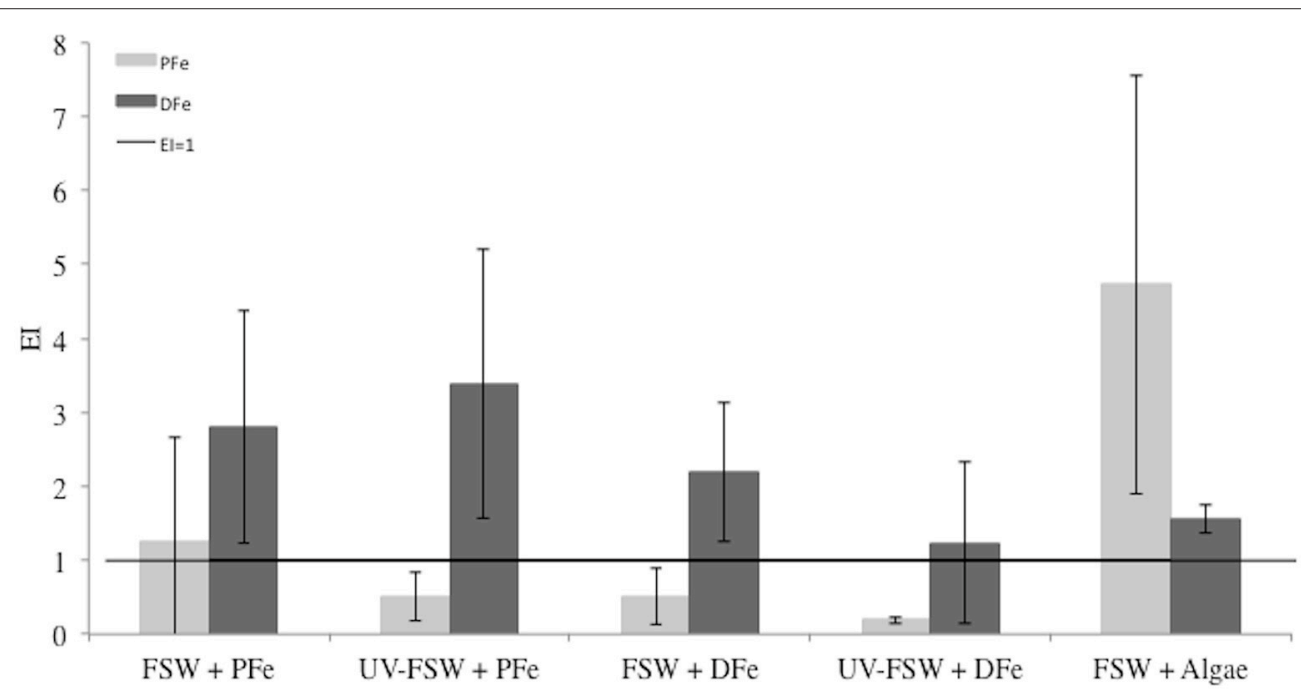

FIGURE 5 | Enrichment indices (EI) of particulate iron (PFe) and dissolved iron (DFe) in each treatment of the Iron Exp. The error bars represent the standard deviation between triplicates $(n=3)$. The black line shows the limit between enrichment $(E l>1)$ or depletion $(E \mid<1)$ of PFe or DFe.

except $\mathrm{NH}_{4}^{+}$as previously observed in natural young ice samples (Janssens et al., 2016) and sea-ice tank experiments (Zhou et al., 2014). In this study, the geometry of the ice crystal grown at 3 different temperatures in the Ice texture Exp. do not show any difference. This indicates that selection of the freezing temperature for the next set of experiments did not influence estimated EIs. The freezing temperature was chosen to resemble a realistic temperature encountered in the field in winter, but was somewhat constrained by the minimum temperature of the circulating water bath.

\section{Extracellular Polymeric Substances, POC, PON, and Macro-Nutrients Experiments POC, PON, and EPS}

EPS from deep seawater were the least enriched in the ice, although it had the highest initial concentration $(0.10 \mu \mathrm{g}$ xeq 


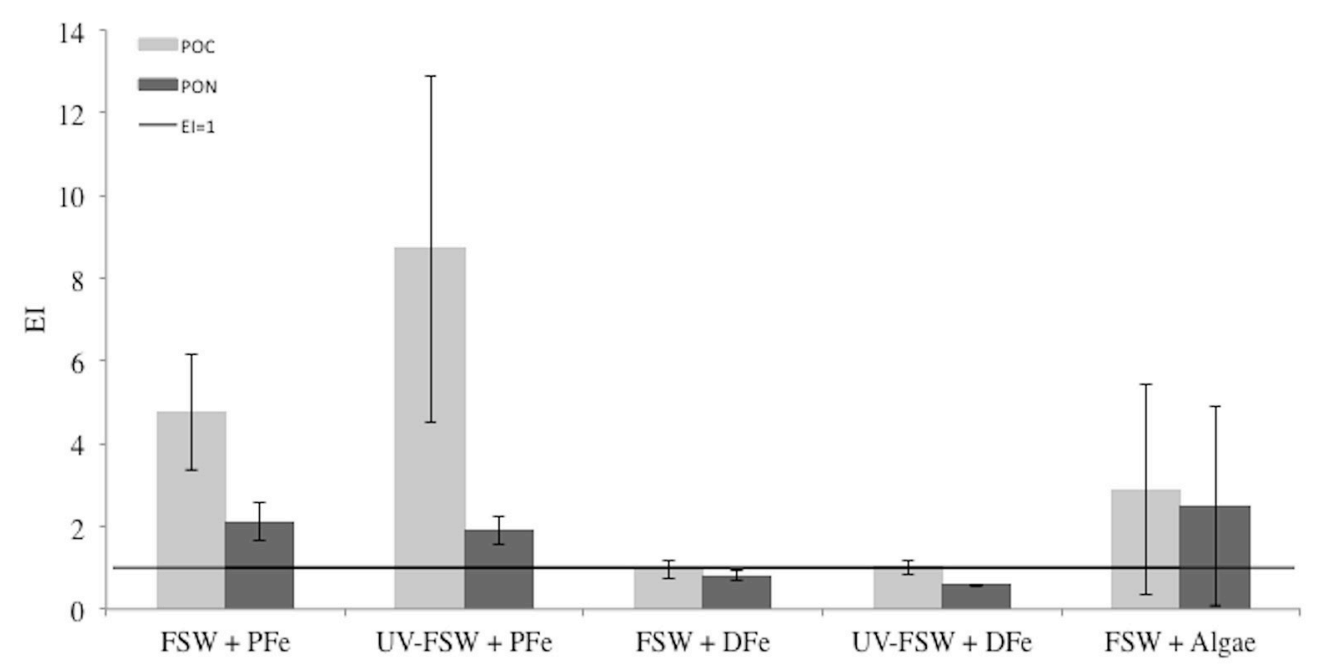

FIGURE 6 | Enrichment indices (EI) for POC and PON in each treatment of the Iron Exp. The error bars represent the standard deviation between triplicates $(n=3)$. The black line shows the limit between enrichment $(E \mathrm{C}>1)$ or depletion $(\mathrm{El}<1)$ of $\mathrm{POC}$ or PON.

$\mathrm{L}^{-1}$ ). Also, the addition of $\mathrm{XG}$, a reference standard for EPS in marine environments (Passow and Alldredge, 1995), did not show a preferential enrichment compared to the natural EPS in other treatments. Deep-sea bacteria have been found to produce EPS (Mancuso Nichols et al., 2005b), and it could be that deep-water EPS have different surface properties (e.g., number of anionic groups) or molecular weights than EPS produced in surface waters. Decho (1990) reported that physicochemical characteristics of EPS are influenced by their tertiary structure, which is dependent on the frequency and type of functional groups presence on the EPS. This could also affect the incorporation efficiency, with stickier EPS being more enriched (Meiners and Michel, 2017). These divergences in surface properties of EPS could also play an important role in the incorporation of $\mathrm{NH}_{4}^{+}$in this experiment. The highest $\mathrm{NH}_{4}^{+}$ enrichment was found when EI $\mathrm{EPS}_{\mathrm{BS}}$ was the lowest (Figure 3). EPS have a negatively charged surface due to the high content of poly-anionic sugars. They are stabilized by the presence of cations (such as e.g., $\mathrm{K}^{+}$and $\mathrm{Ca}^{2+}$ ) (Kloareg and Quatrano, 1988; Verdugo et al., 2004). Also, the sticky properties of EPS determine the interaction of EPS with other components of the marine environment (Passow, 2002). Some authors (e.g., Krembs et al., 2002a; Meiners and Michel, 2017) have suggested that the negatively charged EPS would complex with $\mathrm{NH}_{4}^{+}$, and helped by their stickiness, lead to the enrichment of $\mathrm{NH}_{4}^{+}$and EPS in the ice (Fripiat et al., 2017). However, the lack of correlation between EPS and $\mathrm{NH}_{4}^{+}$in our study does not support this hypothesis, and further study is needed to decipher this process. Microbial regeneration of $\mathrm{NH}_{4}^{+}$has been previously observed in young sea ice (Riedel et al., 2007). However, due to the short duration of our experiment we believe microbial regeneration alone cannot fully explain the enrichment of $\mathrm{NH}_{4}^{+}$in the ice. In an ice tank study, Krembs et al. (2011) found that concentrations of EPS were higher in the ice when Melosira arctica, a diatom found in Arctic sea ice, was added to the source solution compared to ice grown from saline solution containing different concentrations of XG, even if the concentration of XG was higher than the concentration of EPS produced by the diatom. Similarly, using a cold-finger apparatus similar to ours, Ewert and Deming (2011) showed that only native EPS produced by a cold-adapted marine bacterium (commonly found in sea ice) was preferentially incorporated in sea ice. Our results indicating that EPS from surface seawater are enriched in sea ice when compared to deep seawater are consistent with these previous findings, suggesting that the quality of EPS is a key parameter for its entrapment into sea ice.

Higher $\mathrm{EI}_{\mathrm{POC}}$ than $\mathrm{EI}_{\mathrm{PON}}$ are in line with previous reports of high POC and PON concentrations in young Antarctic sea ice (Janssens et al., 2016). In our laboratory study, POC and PON were more enriched in experiments using Antarctic unfiltered seawater compared with experiments conducted with filtered source solutions from Tasmania (Iron Exp.). The presence of biogenic material (phytoplankton, bacteria and EPS) in the unfiltered Antarctic sample could explain this higher enrichment compared to the filtered Tasmanian seawater sample. Also, similar to EPS, the quality of POC may control the degree of enrichment in sea ice. Due to its location, the coastal Tasmanian sampling site is under influence of terrestrial inputs bringing large amounts of allochtonous material to the pool of organic matter. This is in contrast to the Antarctic sampling sites, where the organic matter in the water column is mainly autochtonous. Zhou et al. (2014) showed that riverine DOM was less enriched in sea ice compared to autochtonous DOM, due to different molecular compositions, different affinity with other compounds, and with sea ice. Similarly, Müller et al. (2013) showed that the degree of dissolved organic carbon (DOC) enrichment depends on the chemical characteristics of the DOM. Our results suggest that the POC of potential terrestrial origin is less enriched in sea ice than the autochtonous Antarctic POC, by an order of magnitude. The reason why the POC is preferentially 


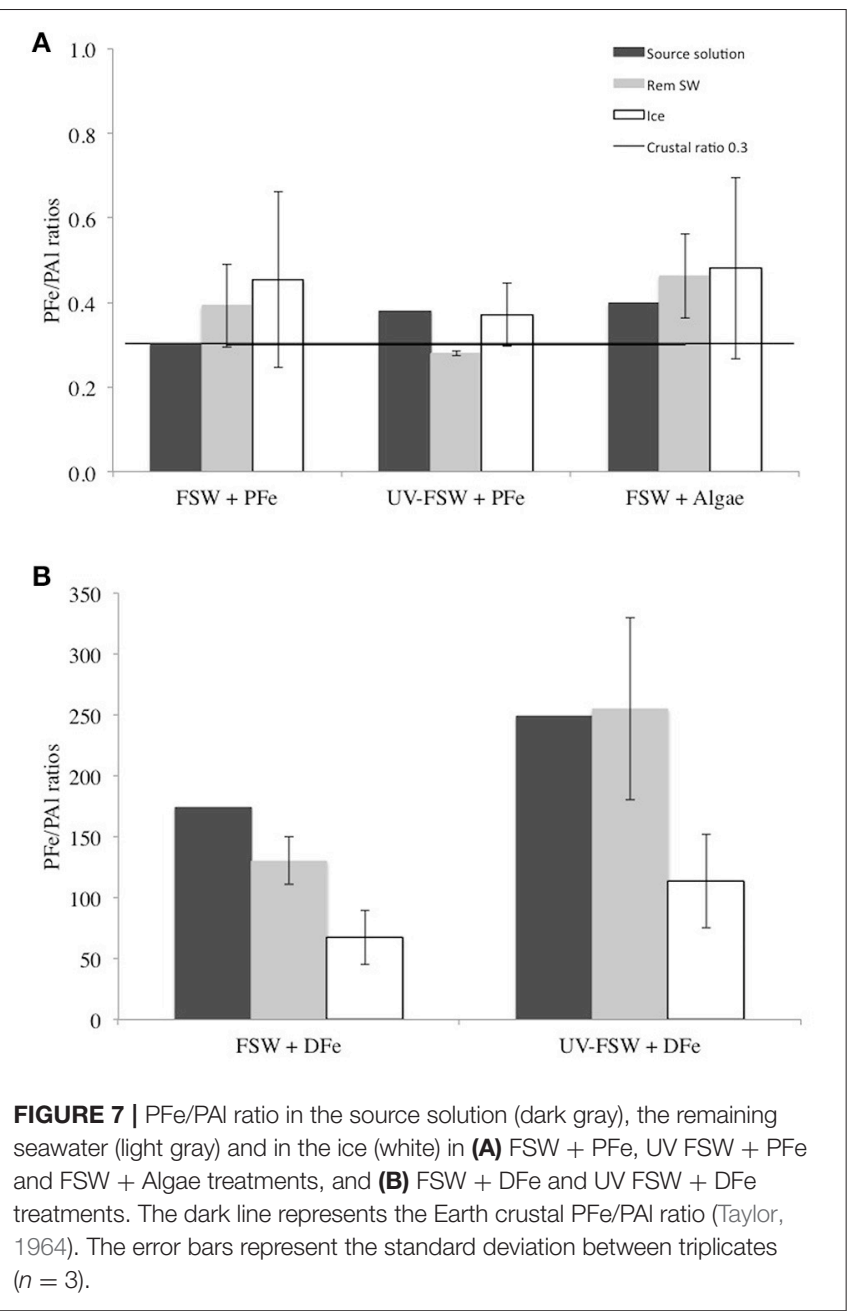

incorporated in the ice compared to PON remains unclear at this stage and this needs further investigations. One idea is EPS might have a higher POC/PON ratio or the organic matter in the ice comprises a mixed composition of live and dead material, with a higher carbon content relative to nitrogen.

\section{Iron Experiments \\ Lithogenic vs. Biogenic Iron: Role of EPS Produced by Ice Algae and Bacteria}

The EIPFe in FSW + Algae was found to be up to 4 times higher than in any other treatment, suggesting a better incorporation of the biogenic PFe compared to the lithogenic PFe. The bottom ice sample added to the FSW + Algae treatment was dominated by pennate diatoms such a Nitzschia stellata, N. lecointei, Fragillariopsis spec., and Entomoneis kjellmanii (Andreas Seger and Fraser Kennedy, personal communication). The large size of algal cells compared to the dust sample, may have lead to the preferential enrichment of biogenic PFe relative to lithogenic PFe. The added dusts were sieved through $20 \mu \mathrm{m}$ nylon mesh, while mentioned diatom species can be as large as $150 \mu \mathrm{m}$ in cell size (Scott and Marchant, 2005), and can also form colonies and ribbon-chain like assemblages (Scott and Marchant, 2005; Aslam et al., 2012). Better incorporation of larger cells and impurities has been previously observed in natural young sea ice (Gradinger and Ikävalko, 1998; Riedel et al., 2007; Rózanska et al., 2008; Janssens et al., 2016).

Algal-bound EPS could also play a role in the incorporation of PFe into sea ice. Assemblages of diatoms are predominant in autotrophic-dominated sea-ice habitats and known to be associated to, and the main producers of, EPS (Krembs and Engel, 2001; Meiners et al., 2003, 2004; Mancuso Nichols et al., 2005a,b; Underwood et al., 2010, 2013). Particulate EPS have been shown to be likely of algal origin and quickly enriched into sea ice (Meiners et al., 2003; Riedel et al., 2007). EPS enrichment has been previously observed in cold-finger (Ewert and Deming, 2011) and ice tank experiments (Krembs et al., 2011). Negatively charged EPS (Decho, 1990; Mancuso Nichols et al., 2005a) are considered to be important in binding cationic metals like $\mathrm{Fe}^{3+}$ and $\mathrm{Fe}^{2+}$. In return, $\mathrm{Fe}$ provides some stability to the EPS network by acting as bridging ions (e.g., Brown and Lester, 1982; Decho, 1990).

Finally, EPS are two to four orders of magnitude stickier than other particles (Passow, 2002), therefore potentially further helping the adhesion of PFe to ice surfaces. One can therefore assume that EPS were an important component of the added melted bottom ice sample to the source solution in the FSW + Algae treatment, contributing to the preferential enrichment in biogenic PFe compared to lithogenic PFe. Krembs et al. (2011) showed that the presence of EPS in the ice changes the microstructure of the ice and alters it physical properties. Thus, it is also possible that these modified properties are beneficial for PFe incorporation (more adapted shape of the pores and an increased internal sea ice surface area) but this requires further investigation.

The DFe fraction was less affected by the addition of algae than the PFe fraction. EPS range in size from sub-microns to hundreds of microns in the marine environment (Passow and Alldredge, 1995). EPS produced by sea-ice algae are known to be in the colloidal and soluble form (Aslam et al., 2012). In this study, a size distinction of $0.4 \mu \mathrm{m}$ was used to define the dissolved and particulate fractions. This definition is however operationally defined and organic matter actually consists of a size continuum spanning across the soluble, colloidal and particulate size fractions. The colloidal material is operationally in the dissolved fraction as it is defined as the fraction that can pass through a filter with pore size of 0.1 to $0.46 \mu \mathrm{m}$ (Chin et al., 1998). van der Merwe et al. (2009) suggested that organicallybound DFe in the ice shows reduced loss to the water column when brine drainage occurs by being associated with particles or cells (Sunda, 2001). The retention of DFe by EPS could explain the lower $\mathrm{EI}_{\mathrm{DFe}}$ in the UV-treated FSW + DFe experiment.

\section{Effect of UV Treatment on Fe Incorporation Efficiency: Importance of Organic Ligands}

When subject to high UV exposure, DOM is degraded and ultimately transformed into carbon dioxide $\left(\mathrm{CO}_{2}\right)$ and water $\left(\mathrm{H}_{2} \mathrm{O}\right)$. The UV- and non UV-treated experiments aimed at understanding the role of organic matter, including organic 
ligands such as EPS, in the incorporation of Fe into sea ice. It has been shown that photochemical reactions alter the concentration and reactivity of the organic ligands involved in the complexation/solubilisation of trace metals (Moffett, 1995). More specifically, photochemical reduction of organically bound Fe decreases ligand-binding strength, rendering the complexed Fe more labile and increasing its bioavailability (Barbeau et al., 2001).

In this study, Fe was added to seawater solutions after UV treatment. While results between UV and non-UV treatments were not statistically significant, different enrichment behaviors for Fe and organic matter were observed between UV-treated and non-UV treated source solutions. The lack of statistical significance is a result of the large variance of the data set compared to the limited size of the data set. Further studies are needed to elucidate the full impact of UV treatment on the incorporation of organic matter into sea ice.

Nevertheless, as expected, DFe (and PFe) enrichment decreased when UV treatment was applied to FSW + DFe. This experiment suggests that the presence and quality of organic matter influences the incorporation of DFe into growing sea ice. However, DFe enrichment increased when UV treatment was applied to FSW + PFe. In the former treatments, the DFe was not present in excess; as such precipitation of DFe into PFe was not observed (see section Conversion of Dissolved Fe to Particulate Form). It is suggested that, in the latter case, the UV treatment resulted in the release of dissolved organic ligands from the degradation of particulate organic matter. These "newly-formed" ligands were then able to complex DFe and carry DFe into sea ice leading to higher $\mathrm{EI}_{\mathrm{DFe}}$ in UV-FSW + PFe than in FSW $+\mathrm{PFe}$, where dissolved organic ligands were more sparse. The difference in enrichment efficiency of DFe in (UV-)FSW $+\mathrm{PFe}$ and (UV-)FSW + DFe by a combined effect of "ligand saturation" and precipitation of DFe into PFe can be explained in this way (see section Conversion of Dissolved Fe to Particulate Form). The UV-broken bound effect might have been compensated by the production of new dissolved organic ligands available for DFe. However, not enough dissolved organic ligands were present in solution to keep the added $30 \mu \mathrm{M}$ of DFe in solution in the FSW + DFe treatment. Free DFe remaining in seawater therefore precipitated into $\mathrm{PFe}$ (see section Conversion of Dissolved Fe to Particulate Form), leading to the high $\mathrm{PFe} / \mathrm{PAl}$ ratios observed.

As observed in the case of DFe incorporation in the (UV-)FSW + DFe treatments, PFe enrichment decreased when UV treatment was applied to FSW + PFe and FSW + DFe. This indicates the role of organic matter in the incorporation of PFe in growing sea ice. Unlike $\mathrm{EI}_{\mathrm{PFe}}$ and $\mathrm{EI}_{\mathrm{DFe}}$, $\mathrm{EI}_{\mathrm{POC}}$ increased when UV treatment was applied to FSW + PFe. It has been proposed that UV-B radiation breaks down not only DOC but also POC (UNEP, 1999), although the effect of UV on particulate organic matter is not clearly defined. Results here show that UV could impact on the quality of POC (including EPS) leading to different incorporation behaviors. It is likely that the POC becomes smaller when UV is applied and is then more easily incorporated into the ice. This argument however contradicts what has been previously observed in the field, where large particles are preferentially incorporated in sea ice (Gradinger and Ikävalko, 1998; Riedel et al., 2007; Lannuzel et al., 2014b; Janssens et al., 2016).

One explanation is that UV-radiation changes the physicochemical properties of organic matter in a way that the PFe-organic matter binding capacity would be reduced, but the enrichment of POC would be favored. Organic-free $\mathrm{PFe}$ would therefore be hardly incorporated, while the UVinduced modifications in the POC facilitate its incorporation. It has been shown that the binding potential of EPS is greatly influenced by their physico-chemical properties (Krembs and Deming, 2008; Verdugo, 2012), which are likely to be altered by UV irradiation. Therefore, more than the size, the important factor for enrichment of particles would be their physico-chemical properties and the tertiary structure/molecular composition/shape of the particles. Zhou et al. (2014) suggested that organic matter is initially incorporated as particulate organic matter and then converted into DOM once in the ice. This process may be observed in the FSW + Algae treatment, with the transformation of POC into DOC by heterotrophic organisms, leading to lower EIPOC than in (UV-)FSW + PFe. However, we note that $8 \mathrm{~h}$ of incubation time may not be sufficient for significant transformation. Zhou et al. (2014) also showed that different quality of DOC impacts the incorporation efficiency. It is suggested that this mechanism is also applicable to particulate constituents as discussed in section Lithogenic vs. Biogenic Iron: Role of EPS Produced by Ice Algae and Bacteria.

\section{Conversion of Dissolved Fe to Particulate Form}

The $\mathrm{PFe} / \mathrm{PAl}$ ratios measured in the samples can give an indication on the level of conversion of DFe into PFe. The addition of $\mathrm{DFe}$ into seawater led to very high $\mathrm{PFe} / \mathrm{PAl}$ ratios in the FSW + DFe and UV-FSW + DFe experiments (Figure 7B). A significant amount of $\mathrm{DFe}(30 \mu \mathrm{M})$ was added to these 2 solutions, without addition of organic ligands (e.g., EDTA) to balance the addition of DFe and keep it in solution. Organic ligands can be produced in situ by sea-ice algae and bacteria (Lannuzel et al., 2015) or supplied externally from e.g., sediment resuspension (Croot and Johansson, 2000; Buck et al., 2007). EDTA is synthetically produced and is therefore not an adequate model ligand of the natural environment.

The conversion observed here of the non-organically bound excess of DFe into the PFe pool (Lannuzel et al., 2014a, 2015), leads to the high $\mathrm{PFe} / \mathrm{PAl}$ ratios observed. This process was even more expressed in the UV-FSW + DFe treatment, where the UV exposure likely broke the bounds of the Fe-ligand complexes already present in the source solution before addition of DFe. The newly formed $\mathrm{PFe}$ and remaining $\mathrm{DFe}$ could be then less prone to incorporation into sea ice, as observed by lower $\mathrm{EI}_{\mathrm{PFe}}$ and $\mathrm{EI}_{\mathrm{DFe}}$. Two explanations are possible: (1) As previously mentioned in the preceding section, biogenic PFe (low in these experiments) is preferentially enriched in the newly-formed ice compared to lithogenic PFe. A decoupling between biogenic and lithogenic PFe incorporation could be observed. EPS have been proposed to be acting as a "plug," retaining salinity in the ice (Krembs et al., 2011). If the biogenic PFe is incorporated first, helped by the association to, and then retained in the ice by EPS, the incorporation of lithogenic PFe might not be as efficient and 
could reach a concentration threshold in the ice. The association of Fe with EPS, as well as the space available in the brine channel system would therefore determine the incorporation, retention, and threshold of PFe in the ice.

(2) Organic ligands may play a key role in transferring DFe from seawater to sea ice. Organically-bound Fe would take advantage of the properties of the particles it is attached to, to get trapped in the ice as discussed previously (section Effect of UV Treatment on Fe Incorporation Efficiency: Importance of Organic Ligands).

It is difficult to distinguish the contribution of each process in these experiments and it is likely a combination of both. We note that Fe concentrations in these experiments were above the range of concentrations encountered in the Southern Ocean, although they are in the range of concentration found in Antarctic fast ice (Grotti et al., 2001; van der Merwe et al., 2011a,b; Noble et al., 2013). All conclusions in this study are derived from a high concentration scenario in regards to added DFe and PFe, but nonetheless, our results provide key information on the general chemistry of the involved processes.

\section{Limitations of Laboratory Ice-Growth Experiments}

Laboratory experiments offer a unique opportunity to study ice growth from its initial stage of ice formation while the history of a natural ice floe is difficult to assess. Laboratory experiments allow the isolation of processes occurring at the onset of ice formation, and the study of the influence of specific parameters, while controlling others. Most importantly, replicate measurements are possible in the laboratory while field sampling of a natural ice floe always carries the uncertainty of high spatial heterogeneity (e.g., Meiners et al., 2012, 2017; Williams et al., 2015).

However laboratory based ice-growth experiments also present some drawbacks. First, ice growth is limited in space (a few $\mathrm{cm}^{3}$ ) and time (a few hours). In the cold-finger case, the geometry of the system is different from natural ice. Ice crystals are mainly growing horizontally (Figure 2), while natural columnar ice exhibits vertical ice crystals. Nonetheless, the good agreement between laboratory-based results and field studies shows that the initial incorporation of solutes and particles over a short period of time is not affected by the geometry of the ice. The cold-finger set-up is, therefore, a useful tool to complete field data and isolate processes to gain a mechanistic understanding of sea-ice biogeochemical processes.

\section{CONCLUSION}

This study represents the first study of processes of Fe enrichment in sea ice under laboratory conditions. The investigation suggests an important role of EPS and POC in the enrichment of PFe in sea ice. Results also indicated that large particles of biogenic PFe derived from sea ice algae are preferentially enriched compared to smaller particles of lithogenic PFe derived from continental dust. Combined these results indicate that rather than the quantity, it is the quality of EPS and POC that determines their rate of entrapment in the ice, with autochtonous POC being more enriched than allochtonous POC. The mechanisms remain unclear, but characterizations of these particles would be a step forward to understand the complex links between $\mathrm{Fe}$ and organic matter incorporation into sea ice. The quality of particulate organic matter determines its association with PFe, and ultimately the efficiency of PFe incorporation in sea ice. UV treatment likely alters organic matter and modifies its association with $\mathrm{Fe}(\mathrm{PFe}$ and $\mathrm{DFe})$. This ultimately affects their degree of enrichment. In the context of changing sea-ice environments, it is important to clearly identify the drivers and to quantify the processes that affect ice-associated Fe and carbon biogeochemical cycling in polar waters.

\section{AUTHOR CONTRIBUTIONS}

JJ, KM, and DL: contributed to conception and design; JJ, KM, AT, and DL: contributed to acquisition of data; JJ, KM, AT, and DL: contributed to analysis and interpretation of data; JJ, KM, AT, and DL: drafted and revised the article; JJ, KM, AT, and DL: approved the submitted version for publication.

\section{FUNDING}

This work was funded by the Australian Research Council (LE0989539 and DE120100030), the Australian Government's Cooperative Research Centres Programme through the Antarctic Climate \& Ecosystems Cooperative Research Centre (ACE CRC) and the Australian Antarctic Science (AAS) projects 4051 and 4298. JJ was supported by the Quantitative Antarctic Science Program jointly led by the University of Tasmania and the Australian Antarctic Division.

\section{ACKNOWLEDGMENTS}

The authors thank the officers and crew of $R V$ Polarstern for their logistical support, as well as the colleagues from the biogeochemical group during the AWECS voyage. We thank Rob King and Tasha Waller from the Australian Antarctic Division for assistance with the collection of the seawater used in the Iron Experiment. We also thank Simon Wotherspoon for assistance with the statistical analysis.

\section{REFERENCES}

Arzel, O., Fichefet, T., and Goosse, H. (2006). Sea ice evolution over the 20th and 21th centuries as simulated by current AOGCMs. Ocean Model 12, 401-415. doi: 10.1016/j.ocemod.2005.08.002

Aslam, S. N., Cresswell-Maynard, T., Thomas, D. N., and Underwood, G. J. C. (2012). Production and characterization of the intra- and extracellular

carbohydrates and polymeric substances (EPS) of three sea-ice diatom species, and evidence for a cryoprotective role for EPS. J. Phycol. 48, 1494-1509. doi: $10.1111 /$ jpy. 12004

Barbeau, K., Rue, E. L., Bruland, K. W., and Butler, A. (2001). Photochemical cycling of iron in the surface ocean mediated by microbial iron(III)-binding ligands. Nature 413, 409-413. doi: 10.1038/350 96545 
Bowie, A. R., Townsend, A. T., Lannuzel, D., Remenyi, T. A., and van der Merwe, P. (2010). Modern sampling and analytical methods for the determination of trace elements in marine particulate material using magnetic sector inductively coupled plasma-mass spectrometry. Anal. Chim. Acta 676, 15-27. doi: 10.1016/j.aca.2010.07.037

Brown, M. J., and Lester, J. N. (1982). Role of bacterial extracellular polymers in metal uptake in pure culture and activated sludge-1. Effect of metal concentration. Water Res. 16, 1539-1548. doi: 10.1016/0043-1354(82)90206-8

Buck, K. N., Lohan, M. C., Berger, C. J. M., and Bruland, K. W. (2007). Dissolved iron speciation in two distinct river plumes and an estuary: implications for riverine iron supply. Limnol. Oceanogr. 52, 843-855. doi: 10.4319/lo.2007.52.2.0843

Chin, W.-C., Orellana, M. V., and Verdugo, P. (1998). Spontaneous assembly of marine dissolved organic matter into polymer gels. Nature 391, 568-572. doi: $10.1038 / 35345$

Croot, P. L., and Johansson, M. (2000). Determination of iron speciation by cathodic stripping voltammetry in seawater using the competing ligand. Electroanalysis 12, 565-576. doi: 10.1002/(SICI) 1521-4109(200005)12:8<565::AID-ELAN565>3.0.CO;2-L

Cutter, G., Andersson, P., Codispoti, L., Croot, P., Francois, R., Lohan, M., et al. (2017). Sampling and sample-handling protocols for GEOTRACES cruises. Available at: http://www.geotraces.org/libraries/documents/Intercalibration/ Cookbook.pdf

Decho, A. W. (1990). Microbial exopolymer in ocean environments: their roles in food webs and marine processes. Ocean Mar. Biol. Annu. Rev. 28, 73-153.

de Jong, J., Schoemann, V., Maricq, N., Mattielli, N., Langhorne, P., Haskell, T., et al. (2013). Iron in land-fast sea ice of McMurdo Sound derived from sediment resuspension and wind-blown dust attributes to primary productivity in the Ross Sea, Antarctica. Mar. Chem. 157, 24-40. doi: 10.1016/j.marchem.2013.07.001

de Jong, J. T. M., Stammerjohn, S. E., Ackley, S. F., Tison, J.-L., Mattielli, N., and Schoemann, V. (2015). Sources and fluxes of dissolved iron in the Bellingshausen Sea (West Antarctica): the importance of sea ice, icebergs and the continental margin. Mar. Chem. 177, 518-535. doi: 10.1016/j.marchem.2015.08.004

Else, B., Rysgaard, S., Attard, K., Campbell, K., Crabeck, O., Galley, R., et al. (2015). Under-ice eddy covariance flux measurements of heat, salt, momentum, and dissolved oxygen in an artificial sea ice pool. Cold Reg. Sci. Technol. 119, 158-169. doi: 10.1016/j.coldregions.2015.06.018

Ewert, M., and Deming, J. W. (2011). Selective retention in saline ice of extracellular polysaccharides produced by the cold-adapted marine bacterium Colwellia psychrerythraea strain 34H. Ann. Glaciol. 52, 111-117. doi: $10.3189 / 172756411795931868$

Fripiat, F., Meiners, K. M., Vancoppenolle, M., Papadimitriou, S., Thomas, D. N., Ackley, S. F., et al. (2017). Macro-nutrients concentrations in Antarctic paci ice: overall patterns and overlooked processes. Elem. Sci. Anthr. 5:13. doi: 10.1525/elementa.217

Galley, R., Else, B., Geilfus, N.-X., Hare, A., Isleifson, D., Ryner, L., et al. (2013). Morphology and distribution of liquid inclusions in young sea ice as imaged by magnetic resonance. Cryosph. Discuss. 7, 4977-5006. doi: 10.5194/tcd-7-4977-2013

Geilfus, N.-X., Delille, B., Verbeke, V., and Tison, J.-L. (2012). Towards a method for high vertical resolution measurements of the partial pressure of $\mathrm{CO}_{2}$ within bulk sea ice. J. Glaciol. 58, 287-300. doi: 10.3189/2012JoG11J071

Gradinger, R., and Ikävalko, J. (1998). Organism incorporation into newly forming Arctic sea ice in the Greenland Sea. J. Plankton Res. 20, 871-886. doi: $10.1093 /$ plankt/20.5.871

Grasshoff, K., Kremling, K., and Ehrhardt, M. (2009). Methods of Seawater Analysis, 3rd Edn. Weinheim; New York, NY; Chiester; Brisbane, QLD; Singapore; Toronto, ON: Wiley-VCH.

Grotti, M., Soggia, F., Abelmoschi, M. L., Rivaro, P., Magi, E., and Frache, R. (2001). Temporal distribution of trace metals in Antarctic coastal waters. Mar. Chem. 76, 189-209. doi: 10.1016/S0304-4203(01)00063-9

Grotti, M., Soggia, F., Ianni, C., and Frache, R. (2005). Trace metals distributions in coastal sea ice of Terra Nova Bay, Ross Sea, Antarctica. Antarct. Sci. 17, 289-300. doi: 10.1017/S0954102005002695

Janssens, J., Meiners, K. M., Tison, J.-L., Dieckmann, G., Delille, B., and Lannuzel, D. (2016). Incorporation of iron and organic matter into young Antarctic sea ice during its initial growth stages. Elem. Sci. Anthr. 4:123. doi: 10.12952/journal.elementa.000123
Kloareg, B., and Quatrano, R. S. (1988). Structure of the cell walls of marine algae and ecophysiological functions of the matrix polysaccharides. Oceanogr. Mar. Biol. Annu. Rev. 26, 259-315.

Kovacs, A. (1996). Sea Ice. Part 1. Bulk Salinity Versus Ice Floe Thickness. CRREL report; 96-7. Hanover, NH: US Army Cold Regions Research and Engineering Laboratory.

Krembs, C., and Deming, J. W. (2008). "The role of exopolymers in microbial adaptation to sea ice," in Psychrophiles: From Biodiversity to Biotechnology, eds R. Margesin, F. Schinner, J. C. Marx, and C. Gerday (New York, NY: Springer-Verlag), 247-264.

Krembs, C., Eicken, H., and Deming, J. W. (2011). Exopolymer alteration of physical properties of sea ice and implications for ice habitability and biogeochemistry in a warmer Arctic. Proc. Natl. Acad. Sci. U.S.A. 108, 3653-3658. doi: 10.1073/pnas.1100701108

Krembs, C., Eicken, H., Junge, K., and Deming, J. W. (2002a). High concentrations of exopolymeric substances in Arctic winter sea ice: implications for the polar ocean carbon cycle and cryoprotection of diatoms. Deep Res. Part I Oceanogr. Res. 49, 2163-2181. doi: 10.1016/S0967-0637(02) 00122-X

Krembs, C., and Engel, A. (2001). Abundance and variability of microorganisms and transparent exopolymer particles across the ice-water interface of melting first-year sea ice in the Laptev Sea (Arctic). Mar. Biol. 138, 173-185. doi: $10.1007 / \mathrm{s} 002270000396$

Krembs, C., Tuschling, K., and Juterzenka, K. (2002b). The topography of the icewater interface - its influence on the colonization of sea ice by algae. Polar Biol. 25, 106-117. doi: 10.1007/s003000100318

Kuiper, M. J., Lankin, C., Gauthier, S. Y., Walker, V. K., and Davies, P. L. (2003). Purification of antifreeze proteins by adsorption to ice. Biochem. Biophys. Res. Commun. 300, 645-648. doi: 10.1016/S0006-291X(02)02900-5

Lancelot, C., de Montety, A., Goosse, H., Becquevort, S., Schoemann, V., Pasquer, B., et al. (2009). Spatial distribution of the iron supply to phytoplankton in the Southern Ocean: a model study. Biogeosciences 6, 4919-4962. doi: 10.5194/bgd-6-4919-2009

Langway, C. (1958). Ice Fabrics and the Universal Stage. Wilmette, IL: U.S. Snow, Ice and Permafrost Research Establishment.

Lannuzel, D., Chever, F., van der Merwe, P. C., Janssens, J., Roukaerts, A., Cavagna, A.-J., et al. (2014a). Iron biogeochemistry in Antarctic pack ice during SIPEX-2. Deep Sea Res. Part II Top. Stud. Oceanogr. 131, 111-122. doi: 10.1016/j.dsr2.2014.12.003

Lannuzel, D., Grotti, M., Abelmoschi, M. L., and van der Merwe, P. (2015). Organic ligands control the concentrations of dissolved iron in Antarctic sea ice. Mar. Chem. 174, 120-130. doi: 10.1016/j.marchem.2015.05.005

Lannuzel, D., Schoemann, V., de Jong, J., Chou, L., Delille, B., Becquevort, S., et al. (2008). Iron study during a time series in the western Weddell pack ice. Mar. Chem. 108, 85-95. doi: 10.1016/j.marchem.2007.10.006

Lannuzel, D., Schoemann, V., de Jong, J., Pasquer, B., van der Merwe, P., Masson, F., et al. (2010). Distribution of dissolved iron in Antarctic sea ice: spatial, seasonal, and inter-annual variability. J. Geophys. Res. 115:G03022. doi: 10.1029/2009JG001031

Lannuzel, D., Schoemann, V., de Jong, J., Tison, J.-L., and Chou, L. (2007). Distribution and biogeochemical behaviour of iron in the East Antarctic sea ice. Mar. Chem. 106, 18-32. doi: 10.1016/j.marchem.2006.06.010

Lannuzel, D., van der Merwe, P. C., Townsend, A. T., and Bowie, A. R. (2014b). Size fractionation of iron, manganese and aluminium in Antarctic fast ice reveals a lithogenic origin and low iron solubility. Mar. Chem. 161, 47-56. doi: 10.1016/j.marchem.2014.02.006

Lemke, P. and Participants of the ANT-XXIX/6 cruise. (2014). The Expedition of the Research Vessel "Polarstern" to the Antarctic in 2013 (ANTXXIX/6). Berichte zur Polar-und Meeresforschung, Helmoltz Gemeinschaft, Bremerhaven, 679.

Loose, B., McGillis, W. R., Schlosser, P., Perovich, D., and Takahashi, T. (2009). Effects of freezing, growth, and ice cover on gas transport processes in laboratory seawater experiments. Geophys. Res. Lett. 36, 1-5. doi: 10.1029/2008GL036318

Mancuso Nichols, C. A., Garon Lardière, S., Bowman, J. P., Nichols, P. D., Gibson, J. A. E., and Guézennec, J. (2005a). Chemical characterization of exopolysaccharides from Antarctic marine bacteria. Microb. Ecol. 49, 578-589. doi: 10.1007/s00248-004-0093-8

Mancuso Nichols, C. A., Guezennec, J., and Bowman, J. P. (2005b). Bacterial exopolysaccharides from extreme marine environments with special 
consideration of the Southern Ocean, sea ice, and deep-sea hydrothermal vents: a review. Mar. Biotechnol. 7, 253-271. doi: 10.1007/s10126-004-5118-2

Meiners, K., Brinkmeyer, R., Granskog, M. A., and Lindfors, A. (2004). Abundance, size distribution and bacterial colonization of exopolymer particles in Antarctic sea ice (Bellingshausen Sea). Aquat. Microb. Ecol. 35, 283-296. doi: $10.3354 / \mathrm{ame} 035283$

Meiners, K., Gradinger, R., Fehling, J., Civitarese, G., and Spindler, M. (2003). Vertical distribution of exopolymer particles in sea ice of the Fram Strait (Arctic) during autumn. Mar. Ecol. Prog. Ser. 248, 1-13. doi: 10.3354/meps 248001

Meiners, K. M., Arndt, S., Bestley, S., Krumpen, T., Ricker, R., Milnes, M. et al. (2017). Antarctic pack ice algae distribution: floe-scale spatial variability and predictability from physical parameters. Geophys. Res. Lett. 44, 7382-7390. doi: 10.1002/2017GL074346

Meiners, K. M., and Michel, C. (2017). "Dynamics of nutrients, dissolved organic matter and exopolymers in sea ice," in Sea Ice $3 r d$ Edn, ed D. N. Thomas (Chichester: John Wiley \& Sons), 415-432.

Meiners, K. M., Vancoppenolle, M., Thanassekos, S., Dieckmann, G. S., Thomas, D. N., Tison, J.-L., et al. (2012). Chlorophyll a in Antarctic sea ice from historical ice core data. Geophys. Res. Lett. 39:L21602. doi: 10.1029/2012GL053478

Moffett, J. W. (1995). Temporal and spatial variability of copper speciation in the Sargasso Sea. Deep Res. Part. I Oceanogr. Res. 42, 1273-1295. doi: 10.1016/0967-0637(95)00060-J

Müller, S., Vähätalo, A. V., Stedmon, C. A., Granskog, M. A., Norman, L., Aslam, S. N., et al. (2013). Selective incorporation of dissolved organic matter (DOM) during sea ice formation. Mar. Chem. 155, 148-157. doi: 10.1016/j.marchem.2013.06.008

Noble, A. E., Moran, D. M., Allen, A. E., and Saito, M. A. (2013). Dissolved and particulate trace metal micronutrients under the McMurdo Sound seasonal sea ice: Basal sea ice communities as a capacitor for iron. Front. Chem. 1:25. doi: $10.3389 /$ fchem.2013.00025

Passow, U. (2002). Transparent exopolymer particles (TEP) in aquatic environments. Prog. Oceanogr. 55, 287-333. doi: 10.1016/S0079-6611(02)00138-6

Passow, U., and Alldredge, A. L. (1995). A dye-binding assay for the spectrophotometric measurement of transparent exopolymer particles (TEP). Limnol. Oceanogr. 40, 1326-1335. doi: 10.4319/lo.1995.40.7.1326

Queroue, F., Townsend, A., van der Merwe, P., Lannuzel, D., Sarthou, G., Bucciarelli, E., et al. (2014). Advances in the offline trace metal extraction of $\mathrm{Mn}, \mathrm{Co}, \mathrm{Ni}, \mathrm{Cu}, \mathrm{Cd}$, and $\mathrm{Pb}$ from open ocean seawater samples with determination by sector field ICP-MS analysis. Anal. Methods 6, 2837-2847. doi: $10.1039 / \mathrm{C} 3 \mathrm{AY} 41312 \mathrm{H}$

Riedel, A., Michel, C., and Gosselin, M. (2006). Seasonal study of seaice exopolymeric substances on the Mackenzie shelf: implications for transport of sea-ice bacteria and algae. Aquat. Microb. Ecol. 45, 195-206. doi: 10.3354/ame045195

Riedel, A., Michel, C., Gosselin, M., and LeBlanc, B. (2007). Enrichment of nutrients, exopolymeric substances and microorganisms in newly formed sea ice on the Mackenzie shelf. Mar. Ecol. Prog. Ser. 342, 55-67. doi: $10.3354 /$ meps 342055

Rintala, J. M., Piiparinen, J., Blomster, J., Majavena, M., Müller, S., Uusikivi, J., et al. (2014). Fast direct melting of brackish sea-ice samples results in biologically more accurate results than slow buffered melting. Polar Biol. 37, 1811-1822. doi: 10.1007/s00300-014-1563-1

Rózanska, M., Poulin, M., and Gosselin, M. (2008). Protist entrapment in newly formed sea ice in the coastal Arctic Ocean. J. Mar. Syst. 74, 887-901. doi: 10.1016/j.jmarsys.2007.11.009

Scott, J. F., and Marchant, J. H. (2005). Antarctic Marine Protists. Canberra; Hobart: Australian Biological Ressources Study; Australian Antarctic Division.

Sedwick, P. N., and DiTullio, R. (1997). Regulation of algal blooms in Antarctic shelf waters by the release of iron from melting sea ice. Geophys. Res. Lett. 24, 2515-2518. doi: 10.1029/97GL02596

Sullivan, C. W., Arrigo, K. R., McClain, C. R., Comiso, J. C., and Firestone, J. (1993). Distributions of phytoplankton blooms in the Southern Ocean. Science 262, 1832-1837. doi: 10.1126/science.262.5141.1832

Sunda, W. G. (2001). "Bioavailability and bioaccumulation of iron in the sea," in The Biogeochemistry of Iron in Seawater, IUPAC Series on Analytical and physical chemistry of environment systems, eds D. R. Turner and K. H. Hunter (Chichester, UK; West Sussex: Wiley), 41-84.
Taylor, S. R. (1964). Abundance of chemical elements in the continental crust: a new table. Geochim. Cosmochim. Acta 28, 1273-1285. doi: 10.1016/0016-7037(64)90129-2

Underwood, G. J. C., Aslam, S. N., Michel, C., Niemi, A., Norman, L., Meiners, K. M., et al. (2013). Broad-scale predictability of carbohydrates and exopolymers in Antarctic and Arctic sea ice. Proc. Natl. Acad. Sci. U.S.A. 110, 15734-15739. doi: 10.1073/pnas.1302870110

Underwood, G. J. C., Fietz, S., Papadimitriou, S., Thomas, D. N., and Dieckmann, G. (2010). Distribution and composition of dissolved extracellular polymeric substances (EPS) in Antarctic sea ice. Mar. Ecol. Prog. Ser. 404, 1-19. doi: $10.3354 /$ meps 08557

UNEP (1999). Executive Summary of the 1998 Report of the Environmental Assessment Panel, in Synthesis of the Reports of the Scientific, Environmental Effects, and Technologies and Economic Assessment Panels of the Montreal protocol, UNEP, United Nations Environment Programme Ozone secretariat.

van der Merwe, P., Lannuzel, D., Bowie, A. R., Mancuso Nichols, C. A. and Meiners, K. M. (2011a). Iron fractionation in pack and fast ice in East Antarctica: temporal decoupling between the release of dissolved and particulate iron during spring melt. Deep Sea Res II. 58, 1222-1236. doi: 10. 1016/j.dsr2.2010.10.036

van der Merwe, P., Lannuzel, D., Bowie, A. R., and Meiners, K. M. (2011b). High temporal resolution observations of spring fast ice melt and seawater iron enrichment in East Antarctica. J. Geophys. Res. 116:G03017. doi: 10.1029/2010JG001628

van der Merwe, P., Lannuzel, D., Mancuso Nichols, C. A., Meiners, K., Heil, P., Norman, L., et al. (2009). Biogeochemical observations during the winter-spring transition in East Antarctic sea ice: evidence of iron and exopolysaccharide controls. Mar. Chem. 115, 163-175. doi: 10.1016/j.marchem.2009.08.001

Verdugo, P. (2012). Marine microgels. Ann. Rev. Mar. Sci. 4, 375-400. doi: 10.1146/annurev-marine-120709-142759

Verdugo, P., Alldredge, A., Azam, F., Kirchman, D., Passow, U., and Santschi, P. (2004). The oceanic gel phase: a bridge in the DOM-POM continuum. Mar. Chem. 92, 67-85. doi: 10.1016/j.marchem.2004.06.017

Wang, S., Bailey, D., Lindsay, K., Moore, K., and Holland, M. (2014). Impacts of sea ice on the marine iron cycle and phytoplankton productivity. Biogeosciences 11, 4713-4731. doi: 10.5194/bg-11-4713-2014

Weissenberger, J., and Grossmann, S. (1998). Experimental formation of sea ice: importance of water circulation and wave action for incorporation of phytoplankton and bacteria. Polar Biol. 20, 178-188. doi: $10.1007 / \mathrm{s} 003000050294$

Williams, G., Maksym, T., Wilkinson, J., Kunz, K., Murphy, C., Kimball, P., et al. (2015). Thick and deformed Antarctic sea ice mapped with autonomous underwater vehicles. Nat. Geosci. 8, 61-67. doi: 10.1038/ngeo2299

Zhou, J., Delille, B., Eicken, H., Vancoppenolle, M., Brabant, F., Carnat, G., et al. (2013). Physical and biogeochemical properties in landfast sea ice (Barrow, Alaska): insights on brine and gas dynamics across seasons. J. Geophys. Res. 118, 3172-3189. doi: 10.1002/jgrc.20232

Zhou, J., Delille, B., Kaartokallio, H., Kattner, G., Kuosa, H., Tison, J.-L., et al. (2014). Physical and bacterial controls on inorganic nutrients and dissolved organic carbon during a sea ice growth and decay experiment. Mar. Chem. 166, 59-69. doi: 10.1016/j.marchem.2014.09.013

Conflict of Interest Statement: The authors declare that the research was conducted in the absence of any commercial or financial relationships that could be construed as a potential conflict of interest.

The reviewer, MV, declared a past co-authorship with one of the authors, $\mathrm{KM}$, to the handling editor.

The reviewer, AN, and handling editor declared their shared affiliation.

Copyright (c) 2018 Janssens, Meiners, Townsend and Lannuzel. This is an open-access article distributed under the terms of the Creative Commons Attribution License (CC $B Y)$. The use, distribution or reproduction in other forums is permitted, provided the original author(s) and the copyright owner are credited and that the original publication in this journal is cited, in accordance with accepted academic practice. No use, distribution or reproduction is permitted which does not comply with these terms. 